\title{
POLA KOMERSIALISASI TEH HIJAU PADA INDUSTRI HOSPITALITY : PANDANGAN PELAKU USAHA
}

\author{
Sigrid Martina ${ }^{1}$, Fitri Abdillah ${ }^{2}$ \\ Fakultas Tourismpreneur, Podomoro University, Jakarta, Indonesia \\ Email : sigrid.martina@podomorouniversity.ac.id
}

\begin{abstract}
Abstrak
Teh adalah produk yang dikonsumsi secara luas dinikmati oleh konsumen di seluruh dunia. Popularitasnya adalah karena manfaat kesehatannya yang terbukti secara ilmiah jika dikonsumsi secara teratur dan benar. Salah satu variannya adalah teh hijau. Namun, permintaan konsumen untuk teh hijau masih relatif rendah secara umum. Tujuan dari penelitian ini adalah untuk menentukan metode yang paling efektif untuk meningkatkan daya jual teh hijau di Indonesia. Metode yang digunakan dalam penelitian ini adalah deskriptif kualitatif, dengan mengumpulkan data dari berbagai pakar teh. Analisis strategis yang digunakan dalam penelitian ini akan menjadi metode pemasaran campuran 7P (produk, proses, orang, harga, tempat, bukti fisik, dan promosi). Hasilnya menunjukkan bahwa, produsen dan produsen teh hijau memerlukan dukungan pemerintah untuk memasarkan teh hijau secara efektif kepada konsumen Indonesia. Langkah paling optimal yang dapat diambil oleh produsen adalah mempromosikan teh hijau di jaringan media lokal, dan promosi melalui acara makanan dan minuman yang relevan. Strategi yang direkomendasikan untuk mempromosikan teh hijau menjadi minuman terkemuka di Indonesia adalah pengembangan produk kantong teh dalam bentuk daun teh, distribusi dan produksi yang melibatkan pemerintah dan petani, membangun pendekatan lain untuk meningkatkan kesadaran tentang teh hijau, mempromosikan berbagai produk teh. ibu kota, promosi dengan produk uji di forum apa pun, dan tidak ada strategi khusus untuk menentukan harga. Disarankan bagi produsen teh hijau untuk memasarkan teh hijau yang unik di berbagai daerah dan provinsi di Indonesia.
\end{abstract}

Kata kunci: komersialisasi, teh hijau, bauran pemasaran, strategi

\begin{abstract}
Tea is a widely consumed product enjoyed by consumers across the world. Its popularity is due to its scientifically proven health benefits if consumed regularly and properly. One of the variants is green tea. However, the consumer demand for green tea remains relatively low in general. The objective of this study is to determine the most effective method to improve the marketability of green tea in Indonesia. The method used in this study will be qualitative descriptive, by collection data from various tea experts. The strategic analysis used in this study will be the mixed marketing method of 7P's (product, process, people, price, place, physical evidence, and promotion). The result shows that, green tea manufacturers and producers require the government's support to effectively market green tea to Indonesian consumers. The most optimal steps that can be taken by producers are to promote green tea in local media networks, and promotion through relevant food and beverages events. The recommended strategy to promote green tea to be leading beverage in Indonesia are product development of tea bags in the form of tea leaves, distribution and production involving the government and farmers, build another approach to increase awareness about green tea, promoting various tea product are capital city, promotion by test product in any forum, and no specific strategy to determine price. It is recommended for green tea producers to market green tea that is unique to teh various regions and provinces of Indonesia.

Keywords: commercialization, green tea, marketing mix, strategy
\end{abstract}




\section{INTRODUCTION}

Teh merupakan salah satu produk minuman yang paling banyak dikonsumsi di seluruh dunia, sebab diyakini teh mempunyai berbagai manfaat. Ajisaka (2012) menyatakan bahwa minum teh dapat meningkatkan kesehatan oleh sebab teh memiliki kadar antioksidan dan zat-zat yang berguna bagi tubuh lainnya. Seiring meningkatnya pengetahuan dan manfaat dari teh, maka makin meningkat pula popularitasnya. Teh adalah salah satu minuman tertua yang memiliki sejarah panjang. Pertama kali diperkenalkan semasa Dinasti Han (206 SM - 220 M) sebagai minuman kerajaan. Teh mulai banyak dikenal oleh masyarakat terjadi semasa Dinasti Tang dan berkembang menjadi industri terjadi pada Dinasti Ming (1368 - 1644 M). Perkembangan lebih pesat dipicu oleh dibawanya teh ke Eropa oleh Portugis dan Belanda yang diikuti dengan penyebaran ke seluruh dunia (Indarto, 2007),

Industri teh berkembang karena meningkatnya permintaan konsumen. Menurut Statista (2018), prospek industri teh sangat menjanjikan, karena pada dekade mendatang sebab nilai pasar teh secara global diprediksi akan meningkat sampai dengan 73.13 milyar dolar pada tahun 2027.

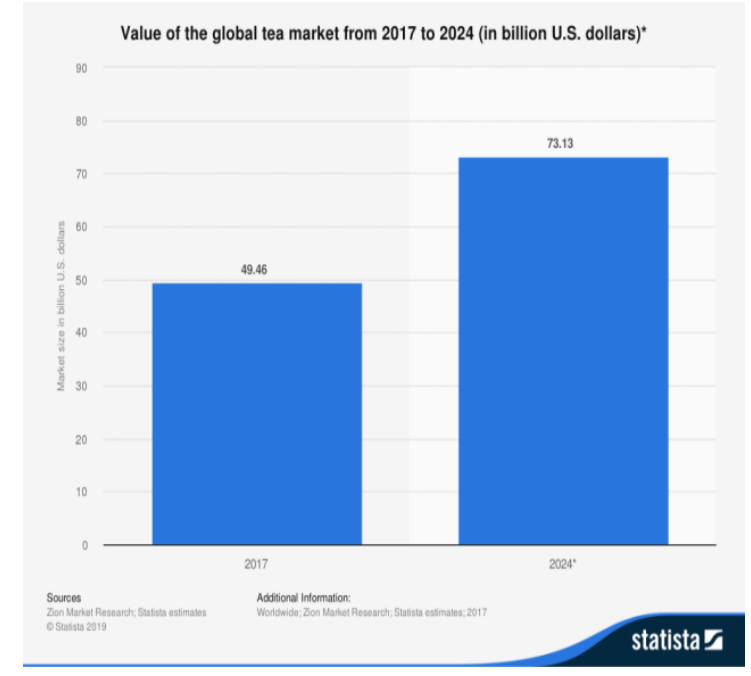

Gambar 1. Nilai Pasar Teh Global (Statista, 2018)
Konsumsi teh local di Indonesia lebih tinggi dibanding dengan produksi untuk ekspor. Hal ini dibuktikan dengan penelitian Rohdiana dan Atmaja (2018), yang menyatakan bahwa serapan teh domestik sudah mencapai $50 \%$ dari total produksi teh dalam negeri yaitu 140.000 ton. Konsumsi teh lokal pada tahun 2019 diperkirakan lebih besar 3\% dibanding tahun sebelumnya. Hal ini juga membuktikan bahwa masyarakat Indonesia juga merupakan peminum teh.

Teh di Indonesia tidak sekedar diminum untuk hidangan sehari-hari, namun telah berubah menjadi tradisi dan gaya hidup. (Utami, 2012). Bagi orang Indonesia, teh merupakan salah satu minuman yang favorit (Meriza et al, 2016). Kebiasaan minum teh di Indonesia tersebar di seluruh wilayah Indonesia. Jenis teh yang dikonsumsi pun tergantung pada kesukaan mereka seperti teh hijau, teh hitam, teh putih, dan teh oolong. Teh juga dipercaya memberikan banyak manfaat bagi kesehatan. Namun demikian dalam hal meminum teh nampaknya masyarakat Indonesia berbeda dengan di negaranegara lain.

Teh diminum lebih kepada penambah rasa. Seringkali minum teh ala Indonesia mengurangi atau bahkan menghilangkan khasiat dari teh itu sendiri. Terdapat beberapa cara mengonsumsi teh yang baik dan benar, salah satunya adalah meminum teh hangat. Teh hangat sangat baik dan bermanfaat bagi kesehatan tubuh kita. Selain itu teh hangat juga memiliki aroma khas dan cita rasa teh itu sendiri. Meminum teh hangat memiliki 74 persen kemungkinan lebih rendah untuk mendapat diagnosis glaukoma (Wu et al., 2017).

Purnama (2019) menunjukkan bahwa dari berbagai jenis teh yang ada, teh hijau masih merupakan jenis teh yang belum populer di Indonesia. Namun seiring dengan berkembangnya industri teh hijau di Jepang maka jenis ini juga turut merebak di Indonesia. Penelitian Apriliani (2015) menyatakan bahwa teh hijau berawal dari restoran-restoran kelas 
menengah di Jakarta. Perkembangan yang terjadi menyebabkan teh hijau tidak hanya digunakan sebagai minuman namun berkembang sebagai bahan pembuat makanan dan kosmetika. Namun demikian penggunaan teh hijau masih sangat terbatas dan belum maksimal dikembangkan, sebab tingkat serapan pasarnya masih rendah. Dari berbagai informasi yang telah disebutkan, nampaknya komersialisasi teh hijau pada industri hospitality di Indonesia masih menjadi diskusi dan wacana bagaimana mengembangkannya. Penelitian ini mencoba menemu-kenali bagaimana mengembangkan metode komersialisasi teh hijau menurut para pelaku industri .

Berdasarkan uraian diatas, maka tujuan dari penelitian ini adalah untuk membuat sebuah strategi pemasaran teh hijau yang mampu diterima di khalayak umum, serta menunjang penentuan kebijakan pemasaran produk teh hijau di Indonesia yang tidak bertentangan dengan cara konsumsi teh hijau yang baik dan benar

\section{METODOLOGI}

Untuk mewujudkan tujuan dari penelitian yang dilakukan, maka metode yang digunakan dalam penelitian ini adalah metode kualitatif deskriptif. Metode ini dilakukan dengan melakukan pencarian informasi mengenai gejala yang ada, merencanakan cara pendekatannya, mendefinisikan dengan jelas tujuan yang akan dicapai, serta melakukan pengumpulan data sebagai bahan untuk pembuatan laporan dengan menggunakan metode riset wawancara. Pendekatan kualitattif dilakukan untuk menjaring informasi yang lebih detail tentang objek yang diteiliti. Pendekatan kualitatif adalah prosedur penelitian yang menghasilkan data deskriptif berupa kata-kata tertulis atau lisan dari orang-orang dan perilaku yang dapat diamati (Moleong, 1989).

Variabel penelitian yang digunakan digunakan pendekatan bauran pemasaran (Kotler and Keller, 2012) meliputi product, price, place, promotion, people, physical evidence, dan process. Penjelasan operasional dari 7P dalam kasus komersialisasi teh adalah sebagai berikut :

Tabel 1. Variabel Pengukuran dan Definisi Operasional

\begin{tabular}{|l|l|l|}
\hline Variabel & Pengukuran & Definisi \\
\hline Product & Kualitatif & $\begin{array}{l}\text { Sesuatu yang ditawarkan untuk dikonsumsi atau } \\
\text { dipakai (teh) }\end{array}$ \\
\hline Price & Kualitatif & $\begin{array}{l}\text { Sejumlah uang yang dibutuhkan untuk } \\
\text { mendapatkan pelayanan ataupun barang }\end{array}$ \\
\hline Place & Kualitatif & $\begin{array}{l}\text { Tempat untuk melakukan suatu usaha atau } \\
\text { aktivitas usaha }\end{array}$ \\
\hline Promotion & Kualitatif & $\begin{array}{l}\text { Cara untuk mengomunikasikan barang maupun } \\
\text { jasa yang akan ditawarkan }\end{array}$ \\
\hline People & Kualitatif & $\begin{array}{l}\text { Sumberdaya manusia yang diperlukan untuk } \\
\text { melakukan aktivitas usaha }\end{array}$ \\
\hline Process & Kualitatif & $\begin{array}{l}\text { Cara pendekatan organisasi agar dapat mengubah } \\
\text { sumber daya menjadi barang maupun jasa }\end{array}$ \\
\hline $\begin{array}{l}\text { Physical } \\
\text { Evidence }\end{array}$ & Kualitatif & $\begin{array}{l}\text { Sesuatu yang paling erat kaitannya dengan situasi } \\
\text { temasuk di dalamnya suasana lingkungan }\end{array}$ \\
\hline
\end{tabular}

Teknik sampling yang digunakan adalah snowball sampling dengan menggunakan informan awal pemilik kedai teh yang sudah dikenal sebelumnya. Informan lain diperoleh berdasar informasi yang diperoleh dari informan pertama tersebut atau penelusuran sumber dari internel. Jumlah informan yang dianggap representative adalah empat orang pelaku usaha atau manajer gerai teh di Jakarta. Informasi yang diperoleh dari keempat orang informan ini dilengkapi dengan observasi yang sudah dilakukan sebelumnya dengan mewawancarai tujuh orang pelaku usaha teh di Jakarta.

Data yang dikumpulkan adalah secara observasi di outlet secara langsung dan wawancara kepada informan yang sudah ditentukan. Observasi dilakukan sebanyak 11 kali dan dari hasil observasi tersebut peneliti membuat field notes, semua observasi dilakukan oleh peneliti dalam jangka waktu 2 bulan dengan hari dan waktu yang berbeda-beda. Hal ini dilakukan untuk mendapatkan hasil observasi yang valid, dan objek 
pengamatan berada dalam kondisi yang tidak dibuat-buat. Menurut Moleong (1989), "Wawancara adalah percakapan dengan maksud tertentu. Percakapan itu dilakukan oleh dua pihak, yaitu pewawancara (interviewer) yang mengajukan pertanyaan dan terwawancara (interviewee) yang memberikan jawaban atas pertanyaan tersebut".

Dalam penelitian ini wawancara yang digunakan adalah wawancara semi terstruktur yaitu wawancara yang pewawancaranya menetapkan sendiri masalah dan pertanyaan-pertayaan yang akan diajukan, dipadukan dengan wawancara terbuka dimana informan bebas untuk menyampaikan informasinya sejauh masih berkaitan dengan bisnis yang ditekuninya, Hal ini diperlukan untuk melengkap inormasi yang diperoleh secara terstruktur mengikuti panduan wawancara

Teknik analisis data yang digunakan oleh peneliti adalah teknik analisis data non statistik yang bersifat deskriptif kualitatif. Data yang didapatkan berupa kumpulan yang berwujud katakata. Data yang didapatkan dari hasil wawancara diproses dengan menggunakan berbagai kata yang disusun ke dalam teks yang diperluas. Kegiatan analisis secara umum terdiri atas tiga alur kegiatan yang terjadi dengan cara bersama, yaitu reduksi data, penyajian data, dan penarikan kesimpulan atau verifikasi. Yang dimaksud dengan tiga alur kegiatan yang terjadi secara bersamaan adalah ketika reduksi data, penyajian data, dan penarikan kesinpulan menjadi sesuatu yang saling jalin menjalin satu sama lain dan mewujudkan proses siklus serta interaksi pada saat sebelum hingga sesudah dilakukannya pengumpulan data. Alur proses pengumpulan dan analisis data dapat dilihat pada gambar berikut :

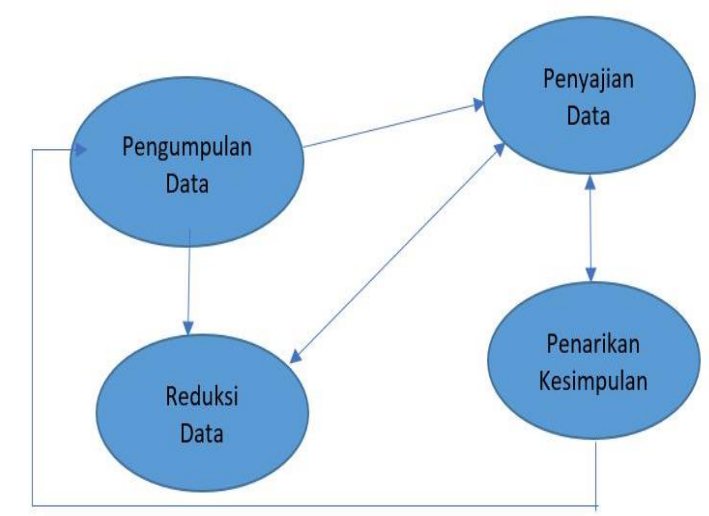

Gambar 2. Analisis Data Model Interaktif Miles dan Huberman (Sugiyono, 2013

\section{RESULT AND DISCUSSION}

Sejarah dan perkembangan teh dijelaskan oleh Somantri (2014) dimana teh pertama kali ditemukan di Tiongkok atau di Assam, India Utara. Kisah mengenai penemuan teh pada awalnya merupakan cerita rakyat yaitu sehelai pohon tersebut kemudian masuk ke dalam air yang dimasak dan diminum olehnya. Setelah kaisar meminumnya rasa letihnya hilang dan ia pun penasaran daun apakah itu. Kemudian daun itu dikenal dengan nama daun teh yang berasal dari pohon teh. Teh tercatat dalam catatan sejarah pada 1066 tahun sebelum masehi yang berasal dari Yunnan, Tiongkok Selatan telah menjadi komoditas yang dikirim sebagai persembahan untuk Kaisar. Teh ini kemudian menyebar ke daerah sekitarnya seperti Assam, Laos, Birma, dan seluruh Tiongkok Selatan. Di Yunnan sendiri terdapat 260 dari 380 varietas teh yang ada dan juga ditemukan pohon teh tertua yang berusia lebih dari 2.000 tahun.

Perkembangan teh di Tiongkok sejak awal ditemukan sehingga populer cukuplah panjang. Pada awalnya teh tidak dikonsumsi sebagai minuman namun sebagai tonic, yaitu minuman penyegar atau minuman kesehatan. Beberapa catatan kuno juga menyebutkan teh disajikan sebagai sup. Lei cha adalah makanan khas suku Hakka yang merupakan salah satu 
contoh dari makanan olahan yang terbuat dari teh.

Kepopuleran teh sendiri, berawal dari zaman Dinasti Tang (618-907M). Namun penyebarannya ke berbagai negara lain di belahan dunia baru terjadi pada Dinasti Qing (1644-1911). Pada era ini teh menyebar keluar Tiongkok, dan Tiongkok sebagai satu-satunya negara pengekspor teh menyebarkannya melalui pelabuhan dagangnya. Pada awalnya teh hanya menyebar di negara-negara sekitar Tiongkok, misalnya saja Jepang pada awal abad ke 8. Namun seiring berjalannya waktu pada abad ke-17 teh pun mulai dibawa ke Eropa. Pada tahun 1637, VOC memperdagangkan teh dari Cina ke negara-negara Eropa dan menjadi populer di berbagai negara di sana.

Pada tahun 1684 tanaman teh masuk pertama kali ke Indonesia. Tanaman ini dibawa oleh seorang warga negara Jerman yang bernama Andreas Cleyer dari negara Jepang. Pada masa itu teh hanya dibudidayakan menjadi tanaman hias. Percobaan penanaman teh dalam skala yang besar belum bisa diimplementasikan karena iklim dari negeri asal teh berbeda dengan iklim di Indonesia Pada tahun 1826 tanaman teh telah berhasil ditanam di Kebun Raya Bogor, dan dikembangkan pada Kebun Percobaan Cisurupan, Garut, Jawa Barat. Pada tahun 1828 perkebunan teh komersial mulai didirikan, hal itu terjadi setelah dilakukannya percobaan penanaman teh berskala besar di Purwakarta dan Banyuwangi. Perkebunan tersebut didirikan oleh Jacobus Isidorus Loudewijk Levian Jacobson yang merupakan seorang ahli teh. Sejak itulah muncul usaha perkebunan teh di Pulau Jawa. "Pada masa pemerintahan Gubernur Van Den Bosch, teh menjadi salah satu tanaman yang harus ditanam rakyat melalui politik Tanam Paksa (Culture Stelsel). Pada 1835, untuk pertama kalinya teh dari Jawa diekspor dan sebanyak 200 peti dilelangkan di Amsterdam."
Pada dasarnya teh yang ditanam di Indonesia merupakan teh jenis sinensis dari Tiongkok, namun karena perubahan iklim hasilnya kurang bagus dan akhirnya pada tahun 1877 teh jenis assamica mulai ditanam dan didatangkan langsung dari Srilangka. Teh jenis assamica tersebut itupun pada akhirnya menjadi mayoritas jenis tanaman teh yang ditanam di Indonesia. Setelah itu, perkebunan di luar pulau Jawa pun mulai didirikan pada tahun 1910. Perkebunan tersebut didirikan di daerah Sumatera Utara, tepatnya di daerah Simalungun.

\section{Perilaku Konsumsi Teh Masyarakat Indonesia}

Teh merupakan minuman berbahan dasar daun dari tumbuhan perdu (Camellia Sinensis) dan merupakan minuman utama sebagian besar masyarakat Indonesia. Tujuan utama minum teh bagi masyarakat Indonesia adalah sebagai penyedap rasa minuman sehari hari sehingga sebagian besar tidak menyadari manfaat-manfaat yang diperoleh dari meminum teh. Konsumsi teh masyarakat Indonesia cukup tinggi walaupun hanya untuk lifestyle (sebagai pengganti minuman kopi) dan tidak banyak orang yang mengetahui cara mengonsumsinya dengan benar. Permintaan konsumsi teh masyarakat Indonesia selalu mengalami peningkatan setiap tahunnya.

Jenis teh yang dikonsumsi masyarakat Indonesia beragam atau semua jenis diminum, Hal ini disebabkan oleh tujuan minum teh adalah penyedap rasa minuman. Beberapa penikmat teh mulai menyadari bahwa penggunaan teh hijau untuk minuman sangat baik bagi kesehatan. Secara umum dari keempat jenis teh yang ada diduga sebagian besar merupakan teh hijau sebab masyarakat Indonesia cenderung tidak peduli membedakan keempat jenis teh yang ada. Manfaat meminum teh diperoleh dengan penggunaan suhu yang tepat disamping takaran, dan penggunaan gula. Penggunaan gula yang berlebihan menyebabkan berkurangnya manfaat dari 
teh. Cara konsumsi teh yang benar adalah dengan membuang air seduhan pertama dan mengonsumsi air seduhan kedua. Air panas digunakan untuk membilas dari kotoran yang menempel.

Cara meminum teh masyarakat berbeda-beda namun secara umum tersaji dalam berbagai pertemuan formal dan informal. Sebagian kecil terutama milenial mulai menikmati produk RTD (ready to drink) sementara sebagian besar masih menikmati teh sebagai sajian yang dipadukan dengan berbagai penganan atau bagi para lansia dinikmati sebagai minuman santai. Cara meminum teh sebagian besar dicampur dengan gula putih.

\section{Strategi Komersialisasi Teh Hijau di Indonesia}

Berdasarkan hasil diskusi dan pembahasan mengenai pertanyaan umum maka dapat disimpulkan bahwa perlu adanya strategi komersialisasi yang dapat mengubah pola konsumsi teh hijau di masyarakat indonesia. Pola komersialisasi produk teh hijau didekati dengan pola bauran pemasaran sebagai berikut.

\section{Product (Produk)}

Teh hijau merupakan produk yang dikenal sebagai produk minuman, namun mulai dikembangkan sebagai produk makanan, minuman, dan kosmetik. Untuk produk kecantikan seperti kosmetik belum begitu dikenal oleh masyarakat. Sedangkan untuk produk makanan seharusnya baik untuk dikonsumsi, akan tetapi campuran gula maupun bahan lainnya membuat khasiat dari teh hijau berkurang atau bahkan tidak direkomendasikan. Sehingga dapat ditarik kesimpulan bahwa produk yang paling memiliki khasiat dan dianjurkan untuk dikonsumsi adalah produk minuman. Produk minuman ini sangat cocok disajikan bersama dengan berbagai kudapan khas masakan Indonesia sebagai appetizer. Palupi and Abdillah (2019) menyatakan bahwa appetizers adalah makanan atau minuman yang merangsang selera (biasanya dilayani sebelum makan atau sebagai yang pertama saja).

\section{Process (Proses)}

Strategi proses distribusi untuk pemasaran teh hijau di Indonesia. Pada proses distribusi teh berdasarkan hasil wawancara, semua informan menyebutkan PTPN atau pemerintah dalam proses distribusi teh di Indonesia. Oleh sebab itu maka pemerintah dalam hal ini berkaitan erat dengan proses distribusi teh dan wajib dilibatkan untuk mengenalkan teh hijau di masyarakat. Sehingga dapat ditarik kesimpulan bahwa strategi untuk proses distribusi teh hijau perlu melibatkan pemerintah di dalamnya.

\section{People (Partisipan)}

Petani teh hijau membudidayakan teh hijau menggunakan cara manual atau tradisional. Cara tersebut sangat tidak efisien di era serba cepat saat ini. Harus diselenggarakan sosialisasi bagi para petani untuk menggunakan cara lain yang lebih efisien. Selain itu sebagian besar informan juga menyatakan bahwa pengedaran teh hijau di Indonesia juga melalui pemerintah atau PTPN dan juga melalui distributor tertentu saja. Karena pemerintah berperan penting dalam pengedaran teh hijau, maka pemerintah harus berupaya untuk mengadakan sosialisasi budidaya teh hijau bagi petani. Sosialisasi tersebut dilaksanakan agar petani dapat membudidayakan teh hijau menjadi lebih optimal. Pemerintah juga dapat bekerja sama dengan petani dalam pengadaan stok teh hijau dan penetapan harga teh hijau berskala nasional. Perusahaan teh hijau yang mengelola teh hijau berdasarkan hasil wawancara adalah perusahaan besar teh seperti Sariwangi, Tong Tji, Twining dan Kepala Djenggot.

Price (Harga)

Harga teh hijau saat ini sudah cukup terjangkau bagi masyarakat, namun hanya untuk merek tertentu belum terjangkau oleh seluruh segmen masyarakat. Dengan demikian maka harga teh hijau sudah cukup terjangkau bagi masyarakat Indonesia. Kegiatan edukasi 
lebih diperlukan untuk menciptakan ceruk pasar khusu yang dimianti pada segmen menengah. Penetapan harga berdasarkan kualitas diurutkan dari semakin tinggi kualitas maka semakin mahal. Strategi yang dilakukan adalah dengan mencari informasi dari pembeli dan memberikan harga lebih untuk distributor.

Untuk strategi tertentu adalah dengan menyimpan teh dengan kualitas yang sangat bagus dan menjualnya ke lelang. Perbedaan pendapat mengenai cara dan strategi penetapan harga teh disebabkan oleh latar belakang informan yang berbeda-beda. Seluruh strategi penetapan harga teh dapat digunakan untuk strategi pemasaran teh. Strategi diskon untuk diterapkan dilakukan apabila stok teh hijau berlebih atau pada seasonal event seperti natal dan ramadhan. Apabila diperlukan, strategi diskon tersebut lebih efektif untuk teh merek mahal agar seluruh produk teh hijau dapat terjangkau bagi seluruh segmen masyarakat.

\section{Place (Lokasi)}

Teh hijau sudah terjangkau bagi masyarakat dan dapat dikonsumsi di area publik. Dengan demikian, tidak diperlukan area khusus untuk konsumsi teh hijau dan teh hijau dapat dijangkau oleh masyarakat umum. Menurut sebagian besar informan, kondisi pasar teh hijau saat ini cukup lemah dan terkendala oleh pemasaran. Karena kondisi pasar yang cukup lemah tersebut memiliki kendala pada pemasaran, maka perlu adanya peningkatan pemasaran teh hijau di masyarakat. Lokasi yang tepat diperlukan untuk meningkatkan pemasaran teh tersebut. Para informan juga menyatakan bahwa rekomendasi untuk lokasi pemasaran teh hijau adalah pada kota besar, event dan acara kuliner, serta iklan media online maupun offline. Lokasi yang telah disebutkan oleh para informan berkaitan antara satu dengan lainnya, seperti kota besar yang memiliki banyak event dan acara kuliner serta media pemasaran. Sehingga dapat disimpulkan bahwa beberapa lokasi seperti kota besar, event dan acara kuliner dapat menjadi tempat untuk menerapkan pemasaran teh hijau dan dapat meningkatkan minat masyarakat. Apabila minat masyarakat meningkat maka kondisi pasar tidak akan menjadi lemah.

\section{Physical Evidence (Lingkungan / pendukung fisik)}

Produk teh hijau di Indonesia tidak memiliki ciri khas tertentu yang berbeda dengan produk teh yang lain. Hal ini sangat sesuai dengan teori yang telah dijabarkan oleh peneliti mengenai teh hijau berasal dari negara lain yang memiliki iklim berbeda. Sehingga produk dari teh hijau di Indonesia tidak memiliki ciri khusus seperti di Jepang dan China, karena merupakan hasil dari modifikasi yang dapat bertahan pada iklim tropis di Indonesia.

Varian produk teh hijau di Indonesia juga tidak memiliki ciri khusus seperti negara lainnya. Menurut hampir dari seluruh informan, stok atau ketersediaan dari produk teh hijau lebih sedikit dibandingkan dengan permintaan atau demand. Seluruh informan juga menyatakan bahwa produksi teh hijau Indonesia mampu bersaing di ranah ekspor negara lain. Kedua pernyataan tersebut sebenarnya sangat berkaitan dan didukung oleh teori peneliti yang telah dijabarkan. Perlu adanya penambahan kuota untuk persediaan teh hijau dalam negeri dari persediaan teh hijau untuk ekspor. Apabila stok untuk ekspor tidak mencukupi untuk dikurangi, maka dapat dilakukan penambahan produksi teh hijau khusus untuk persediaan dalam negeri. Perlu adanya campur tangan dari pemerintah maupun perusahaan yang berkaitan dengan persediaan teh hijau tersebut. Berdasarkan tiga dari empat informan menyatakan bahwa lingkungan yang mendukung penjualan teh hijau adalah divisi food and beverage seperti restoran dan yang tidak mendukung adalah warung atau rumah makan kecil maupun bioskop. Sementara salah satu informan menyatakan bahwa semua lingkungan cocok untuk penjualan teh hijau. Pada lokasi yang mendukung 
untuk penjualan teh hijau sangat tepat untuk dilakukan pemasaran teh hijau. Sehingga dapat disimpulkan bahwa pemerintah sangat berperan penting untuk ketersediaan teh hijau di Indonesia karena sangat berkaitan dengan pemasaran teh hijau dan pemasaran teh hijau akan lebih optimal apabila dilakukan pada tempat yang mendukung untuk penjualan teh hijau.

\section{Promotion (Promosi)}

Pemerintah harus berperan untuk membangun awareness dalam menambah minat masyarakat dalam mengonsumsi teh hijau. Karena pemerintah berpengaruh pada masyarakat dan sangat berperan penting dalam distribusi dan supply teh hijau, maka peran pemerintah sangat penting untuk membangun awareness untuk produk teh hijau. Cara untuk membangun awareness tersebut adalah dengan mengadakan sosialisasi produk teh hijau pada masyarakat. Seluruh informan menyatakan bahwa media promosi yang dapat membantu distribusi teh hijau kepada masyarakat adalah media online seperti sosial media dan media offline seperti TV, pamflet, spanduk. Media tersebut sangat diperlukan karena dapat membangun minat masyarakat sehingga dapat membantu distribusi teh hijau di masyarakat.

Tidak ada kebijakan dan aturan khusus dalam promosi teh hijau sehingga hal tersebut sangat membantu promosi dalam media-media yang telah disebutkan. Selain itu seluruh informan menyatakan bahwa promosi teh hijau juga dapat berlaku dalam platform berbasis online. Hal tersebut memudahkan dalam promosi teh hijau karena era digital saat ini promosi melalui media daring lebih efektif dibanding media lainnya. Namun demikian menurut para informan, strategi promosi teh hijau menggunakan food tasting atau demo langsung di depan masyarakat adalah strategi promosi yang paling efektif untuk masyarakat Indonesia. Karena media online belum sepenuhnya menjangkau seluruh masyarakat indonesia dikarenakan faktor generasi maupun geografis. Sehingga dapat ditarik kesimpulan bahwa strategi promosi yang paling efektif adalah menggunakan food tasting menggunakan teh hijau dengan mempertimbangkan juga sosialisasi teh hijau oleh pemerintah serta pemasaran teh hijau melalui media online.

Perlu adanya penerapan strategi bauran pemasaran yang tepat agar komersialisasi teh hijau dapat berjalan secara optimal. Dari ketujuh strategi bauran pemasaran yang digunakan, yang pertama adalah strategi untuk produk. Strategi produk (product) yang digunakan adalah menggunakan produk minuman teh hijau. Strategi tersebut sangat efektif karena minuman merupakan salah satu produk yang diminati oleh masyarakat Indonesia dan khasiatnya tidak berkurang. Setelah itu untuk strategi proses (process) dapat dilakukan dengan melibatkan pemerintah di dalamnya. Strategi tersebut dilakukan karena pemerintah berperan penting dalam distribusi teh hijau di Indonesia. Strategi partisipan (people) dapat hampir mirip dengan process, yaitu dengan bekerjasama dengan pemerintah untuk sosialisasi teh hijau. Strategi berikutnya adalah strategi harga (price). Strategi diskon tidak diperlukan karena harga sudah cukup terjangkau bagi masyarakat. Namun demikian ada berbagai cara untuk strategi harga, di antaranya adalah dengan penetapan harga berdasarkan dengan kualitas. Setelah itu untuk strategi lokasi (place) beberapa lokasi seperti kota besar, event dan acara kuliner menjadi tempat untuk pemasaran teh hijau. Strategi lingkungan atau pendukung fisik (physical evidence) agak lebih kompleks, yaitu memastikan ketersediaan teh hijau cukup serta melakukan pemasaran di tempat yang tepat. Ketersediaan teh hijau dapat diketahui atau dipastikan apabila kerjasama dengan pemerintah atau pihak terkait dilakukan. Strategi berikutnya adalah strategi promosi (promotion) yang menggunakan media online maupun food tasting. Demo food tasting pada event makanan ataupun minuman yang berkaitan 
dengan teh akan lebih efektif karena masyarakat Indonesia yang beragam dan tidak semuanya dapat mengakses internet. Demikianlah penjabaran mengenai beberapa strategi bauran pemasaran yang dapat dilakukan berdasarkan diskusi dan pembahasan mengenai strategi bauran pemasaran 7P. Strategi bauran pemasaran yang telah dijabarkan tersebut dapat diterapkan agar pemasaran teh hijau menjadi lebih optimal.

\section{KESIMPULAN}

Secara umum teh hijau adalah salah satu dari jenis produk teh yang dikonsumsi oleh masyarakat Indonesia. Strategi komersialisasi teh dijabarkan sebagai berikut.

1. Strategi produk dapat diterapkan dengan menggunakan jenis produk yang digemari oleh orang Indonesia. Selain dari produk makanan dan kosmetik, produk yang paling digemari adalah produk minuman. Produk yang disarankan adalah berbentuk curahan atau tea bag yang masih berbentuk daun teh. Apabila produk minuman yang dipasarkan adalah RTD (ready to drink), maka akan mengurangi khasiat dalam teh hijau.

2. Strategi distribusi dan produksi teh hijau di Indonesia. Distribusi dan produksi teh hijau di Indonesia melibatkan pemerintah dan petani yang bekerja di lahan pemerintah.

3. Strategi partisipan adalah membangun awareness tentang teh hijau sangat diperlukan pada masyarakat Indonesia. Dengan adanya pengenalan teh hijau beserta khasiatnya diharapkan dapat menambah daya tarik teh hijau di mata masyarakat Indonesia dan menambah partisipan dalam distribusi maupun produksi teh hijau.

4. Strategi harga teh hijau sangat berkaitan dengan inovasi produk sebab harga sudah terjangkau namun perlu dipikirkan untuk memberi diskon pada event-event tertentu

5. Strategi lokasi memerlukan tempat yang tepat bagi pemasarannya. Lokasi yang tepat untuk menerapkan strategi bauran pemasaran tersebut adalah kota besar.

6. Strategi lingkungan fisik teh hijau atau bukti fisik berkaitan dengan lingkungan tempat penjual teh hijau dengan konsumen berinteraksi. Diperlukan lingkungan yang sesuai untuk strategi tersebut seperti lingkungan restoran atau yang berkaitan dengan divisi Food \& Beverages. Namun demikian ada beberapa tempat tertentu yang tidak tepat untuk strategi tersebut, yaitu pada warung-warung kecil maupun bioskop. Masyarakat lebih menyukai mengonsumsi teh hijau pada restoran dan kafe.

7. Strategi promosi sangat berkaitan dengan media yang terpublikasi di Indonesia. Baik media online maupun offline sangat sesuai untuk masyarakat Indonesia. Iklan yang terdapat di media mengenai teh hijau dapat memengaruhi daya konsumsi masyarakat Indonesia terhadap teh hijau.

\section{SARAN}

Berdasarkan analisis yang telah dilakukan dari hasil penelitian maka peneliti dapat memberikan saran mengenai strategi komersialisasi teh hijau sebagai berikut:

1. Sebagai salah satu negara produsen teh terbesar di dunia seharusnya Indonesia dapat memiliki produk ciri khasnya sendiri dibanding negaranegara produsen teh lainnya. Indonesia dapat mengadopsi popculture negara tertentu ataupun menciptakan tren produk baru berdasarkan dari budaya yang berkaitan dengan teh yang telah dimiliki. Dengan demikian, produk baru berciri khas Indonesia tersebut 
dapat juga menambah minat konsumsi teh hijau baik dari masyarakat Indonesia maupun dunia.

2. Indonesia kaya akan budaya, terdiri oleh banyak pulau, dan juga kondisi tanah yang berbeda-beda. Pembudidayaan teh hijau disarankan dapat juga dilakukan di luar pulau Jawa. Hal tersebut juga akan melahirkan teh hijau khas tertentu dan dapat juga meningkatkan daya beli masyarakat. Seperti halnya kopi yang memiliki ciri khas geografis provinsi di Indonesia.

3. Perlu lebih adanya promosi yang berkaitan dengan festival ataupun budaya tertentu yang berkaitan dengan teh hijau. Seperti budaya "Nyaneut" di Garut, Jawa Barat yang berkaitan erat dengan komoditas teh yang menjadi ciri khas daerah tersebut. Tradisi teh ala sunda tersebut dapat dilestarikan sampai sekarang dan menjadi budaya turun temurun. Pemerintah dapat mempromosikan festival yang berkaitan dengan teh hijau di luar wilayah yang memiliki budaya tersebut.

4. Mayoritas penduduk Indonesia yang akrab dengan teknologi saat ini diisi oleh anak muda. Salah satu cara untuk menaikkan jumlah konsumen teh hijau adalah dengan menciptakan tren di kalangan anak muda. Apabila generasi saat ini sangat menyukai kopi maka dapat diimplementasikan produk kopi dicampur dengan teh hijau. Atau jika tidak ingin kopi tersebut merusak khasiat teh hijau maka dapat ditambahkan menu teh hijau pada kafe ataupun warung kopi kekinian yang kini makin banyak. Apabila tren teh hijau telah mendapatkan hati generasi tersebut maka teh hijau akan lebih cepat berkembang karena perkembangan teknologi saat ini (melalui internet atau sosial media).

\section{DAFTAR PUSTAKA}

Ajisaka. 2012. Teh Dahsyat Khasiatnya. Surabaya: Stomata.

Anjarsari. (2016). Katekin Teh Indonesia: Prospek dan Manfaatnya. Fakultas Pertanian Universitas Padjajaran. Bandung. Jurnal Kultivasi Vol 15.

Apriliani, Lany (2015), Green Tea (Teh Hijau), Sejarah, Manfaat, dan Trend. Retrieved from http://disbun.jabarprov.go.id/web old/index.php/artikel/detailartikel/ 69

Atmaja, M. I., \& Rohdiana, D. (2018). Diversification of Tea Based Products in the Food, Pharmaceutical and Cosmetic Industry. Perspektif Vol. 17 No. 2, Desember 2018, 150-165.

Grobbink, E. (2012). Strategic commercialization. Netherland: University of Twente.

Handayani, Eva (2014), Trend Kuliner "Green Tea" di Kalangan Anak Muda. Retrieved from http://berita.upi.edu/trend-kulinergreen-tea-di-kalangan-anakmuda/

Indarto, Prawoto (2007). Teh Minuman Bangsa-Bangsa Di Dunia. Pawon Publishing, Jakarta

Jenny C. Servo (1998). Commercialization and Business Planning Guide for the Post-Award Period, Designed Especially for the Technology Entrepreneur, Advanced Technology Program National Institute of Standards and Tech., Tech. Admin is. United States Dep. of Commerce

Kasmir. (2013). Kewirausahaan (Cetakan ke-8). Jakarta: Rajawali Pers.

Keegan, W. J., \& Green, M, C. (2015). Global Marketing. 8th Edition. Upper Saddle River, NJ: Prentice Hall.

Kotler, P. \& Armstrong, G. (2012), Prinsip- Prinsip Pemasaran (Edisi 12). Jakarta: Penerbit Erlangga. 
Linda Carroll and Danielle Wolf (2016). Drinking tea may improve your health. Retrieved from https://www.today.com/series/onesmall-thing/top-10-health-benefitsdrinking-tea-t81111

Liu, Xiona., Xu, Wanghong., Cai, H., Gao, Yu-Tang., Li, Honglan., Ji, BuTian., Shu, Xiang., Wang, Thomas., Gerszten, Robert E., Zheng, W., Xiang, YB., Shu, Xiao Ou. (2018). Green tea consumption and risk of type 2 diabetes in Chinese adults. International Journal of Epidemiology. (Volume 47, Issue 6, December 2018).

Mahmood, T., Akhtar, N., Khan, B. A., Khan, H. M. S., dan Saeed, T., (2010). Outcomes of $3 \%$ green tea emulsion on skin sebum production in male volunteers. Bosn. J. Basic Med. Sci. Udruženje Basičnih Med. Znan. Assoc.Basic Med. Sci., 10(3).

Meriza, F., Lestari, D. A., \& Soelaiman, A. (2016). Sikap Dan Kepuasan Rumah Tangga Konsumen Teh Celup Sariwangi dan Sosro di Bandar Lampung. JIIA, Volume 4 No. 1, 67-75.

Miles, M.B., Huberman, A.M. \& Saldana, J. (2014) Qualitative Data Analysis: A Methods Sourcebook. London:SAGE.

Moleong, Lexy J. 2009. Metodologi Penelitian Kualitatif. Bandung: PT. Remadja Rosdakarya

Palupi, S., \& Abdillah, F. (2019). Local Cuisine as a Tourism Signature. In Delivering Tourism Intelligence. Emerald Publishing Limited.

Pemerintah Australia. (2003). Mapping Australian Science and Innovation: Main Report.

Peters, U., Poole, C., Arab, L. (2001). Does tea affect cardiovascular disease? A meta-analysis. Am. J. Epidemiol.

Purnama, Iqbal D. (2019), Ada 4 Jenis The Di Indonesia, Apa Saja Ya?.
Retrieved

from

https://lifestyle.okezone.com/read /2019/07/25/298/2083541/ada-4jenis-teh-indonesia-apa-saja-ya

Purnama, Iqbal D. (2019), Ada 4 Jenis The

Di Indonesia, Apa Saja Ya?.

Retrieved from

https://lifestyle.okezone.com/read /2019/07/25/298/2083541/ada-4-

jenis-teh-indonesia-apa-saja-ya

Rohdiana, D. (2015). Teh: Proses, Karakteristik dan Komponen Fungsionalnya. Food Review Indonesia.

Samman, S., B. Sandtrom, M.B. Toft, K, Bukhave, M. Jensen, S.S. Sorensen, and M. Hansen. (2001). Green tea or rosemary extract added to foods reduce nonhemeiron absorption. American Journal Clinical Nutrition. 73.

Simamora, Manaek. (2008). Strategi Komersialisasi Aset Kekayaan Intelektual (Intellectual Property Commercialization Strategy). Center for Innovation Indonesian Institute of Sciences; Research Center for Biotechnology, Indonesian Institute of SciencesLIPI. Retrieved from https://dx.doi.org/10.2139/ssrn.27 29265

Somantri, Ratna. (2014). The Story in A Cup of Tea. Jakarta: Trans Media Pustaka.

Statista. (2018). Statista: Global tea market size 2017-2024. Retrieved from https://www.statista.com/statistics /326384/global-tea-beveragemarket-size/

Sugiyono. (2013). Metode Penelitian Kuantitatif, Kualitatif dan R\&D. Bandung: Afabeta.

Syaipulloh. (2011). Statistik Teh Indonesia. Jakarta: Badan Pusat Statistik Republik Indonesia.

Utami, Christina Widya. (2010). Manajemen Ritel. Edisi Kedua. Jakarta: Salemba Empat. 
Watanabe, I., Shinichi K., Masako I., Toshimasa S., Kaori, Naoki N., Atsushi H., and Ichiro T. (2009). Green Tea and Death from Pneumonia in Japan. The Ohsaki cohort study 1-3. Am J Clin Nutr 2009;90:672 -9.

Wu, Connie M., Wu, Annie M., Tseng, Victoria L., Yu, Fei., Coleman, Anne. (2017). Frequency of a diagnosis of glaucoma in individuals who consume coffee, tea and/or soft drinks. UK: The British journal of ophthalmology.

Wulandari, Riska \& Rahmanisa, Soraya. (2016). Pengaruh Ekstrak Teh Hijau terhadap Penurunan Berat Pada Remaja, Jurnal Majority, Vol 5. No 2. Lampung: Universitas Lampung.

Zeithaml, V. A., Bitner, M. J., \& Gremler, D. D. (2013). Services Marketing: Integrating Customer Focus across the Firm. (Edisi ke 6). Boston: Mc.Graw-Hill.

Zowail, M.E.M.; Khater, E.H.H. \& ELAsrag, M.E.M. (2009). Protective effect of green tea extract against cytotoxicity induced by enrofloxacin in rat Egypt. Acad. J. biolog. Sci., 1 (1) 